\title{
Long-term maize stalk retention reduces seedtime soil respiration
}

\author{
Honglei Jia ${ }^{1}$, Hui Guo², Michael J. Walsh³ ${ }^{3}$ John Bennett ${ }^{4}$, Yu Zhang ${ }^{5}$, and Gang Wang ${ }^{\text {* }}$ \\ ${ }^{1}$ Jilin University, College of Biological and Agricultural Engineering, Changchun 130022, China. \\ ${ }^{2}$ Jilin University, Key Laboratory of Bionic Engineering, Changchun 130022, China. \\ ${ }^{3}$ Cornell University, Department of Biological and Environmental Engineering, Ithaca, New York, 14853, USA. \\ ${ }^{4}$ University of Southern Queensland, National Centre for Engineering in Agriculture, West Street, \\ Toowoomba, Queensland, 4350, Australia. \\ ${ }_{5}^{5}$ ilin University, College of Electronic Science \& Engineering, Changchun 130012, China. \\ *Corresponding author (wangganggoodman@163.com).
}

Received: 22 March 2018; Accepted: 9 June 2018; doi:10.4067/S0718-58392018000300350

\begin{abstract}
Cropland soil respiration (Rs) is a major part of $\mathrm{CO}_{2}$ transportation between the atmosphere and terrestrial ecosystems. Stalk retention is an effective method to conduct sustainable agricultural development. However, the relationship between long-term maize (Zea mays L.) stalk retention and seedtime Rs is not yet fully understood; two experimental zones with the same management history were therefore chosen to conduct the comparative study. Rainfed maize monoculture was the only crop cultivated in the study site. One zone (CZ) was covered by $5639 \mathrm{~kg} \mathrm{ha}^{-1}$ maize stalk residue (MSR) after harvesting, and the other zone (BZ) has been left bare since autumn 2000. Annual measurements with 10 replicates were conducted at seedtime in 2015, 2016, and 2017. Results showed that mean Rs was 4.11 and $4.99 \mu \mathrm{g} \mathrm{CO}_{2} \mathrm{~g}^{-1} \mathrm{soil} \mathrm{h}^{-1}$ for CZ and BZ, respectively. Compared with BZ, CZ soil moisture was higher, but its soil temperature was lower. Although soil microbial abundances in $\mathrm{CZ}$ and $\mathrm{BZ}$ had decreasing trends between two adjacent seedtimes, there was a nonsignificant decrease of actinomycetes $(\mathrm{p}>0.1)$ and fungi $(\mathrm{p}>0.1)$ in BZ. The mean percentages of alkyl-carbon (Alkyl-C) were $25.6 \%$ and $35.0 \%$ for $\mathrm{CZ}$ and BZ, respectively. Redundancy analyses (RDA) showed that decreasing soil temperature, soil fungi, Alkyl-C as well as increasing soil moisture could explain reduced Rs in CZ. Maize stalk retention reduces seedtime Rs, thus maize stalk retention might contribute to soil $\mathrm{C}$ sequestration.
\end{abstract}

Key words: Carbon composition, microbial abundance, redundancy analysis, soil fungi, soil moisture, soil temperature, Zea mays.

\section{INTRODUCTION}

Conservation tillage is an effective method to facilitate sustainable agricultural development (Jia et al., 2010). Stalk retention is one of the central components of conservation tillage and the benefits of stalk retention are regionally variable and depend on both agro-climatic and socioeconomic factors; studies from developing countries in Asia, Latin America, and Africa have reported positive effects that include increased soil organic carbon (SOC), soil water retention, and nutrient cycling together with decreased soil loss (Nyakudya and Stroosnijder, 2015; Turmel et al., 2015).

Soil respiration is the $\mathrm{CO}_{2}$ emission process and is the $\mathrm{C}$ flux between the atmosphere and terrestrial ecosystem; furthermore, cropland soil respiration (Rs) also plays an important role in $\mathrm{CO}_{2}$ transportation. Agricultural management greatly influences cropland Rs (Chavarría et al., 2016). For instance, stalk retention changes soil temperature, soil moisture, and soil nutrient status, especially in the tillage layer (Koiter and Lobb, 2008). Inversely, these soil property changes affect Rs (Isla et al., 2016; Qin et al., 2016). Diverse soil temperature experimental results have indicated that the Rs rate is closely related to soil temperature. Soil respiration is one type of enzymatic reaction and, within a certain temperature range, there 
is higher temperature and higher enzymatic activity and vice versa (Wu et al., 2015). Soil respiration is controlled by the thermodynamic law; when the temperature decreases below $0{ }^{\circ} \mathrm{C}$, most microbial activity almost ceases, but when the temperature rises again, most microbial activity increases, although there are some specific differences. Soil respiration does not continue to rise along with increasing temperature; otherwise, Rs declines when temperature exceeds the optimum temperature range (Richardson et al., 2012). Soil moisture is another key factor influencing Rs because it can supply water to soil microbes and plant roots; water is the essential reactant for SOC decomposition by soil microbes. Meanwhile, soil moisture can influence soil aeration, which determines the oxygen content in soil pores, and Rs can only be carried out under oxygen conditions (Fóti et al., 2014). Soil microorganisms play an important role in the SOC decomposition process, soil microbial community, in species characteristics, microbial abundance, and their activity can affect Rs. According to Condron et al. (2010), approximately $85 \%$ to $90 \%$ of SOC was decomposed by soil bacteria and soil fungi. Ran et al. (2010) conducted several experiments in forests and high latitude meadows and their research results indicated that the determination of soil bacteria and soil actinomycete coefficients for Rs were 0.52 and 0.71 , respectively. The carbon $(C)$ substrate is also very important for Rs. Both the quality and quantity of the $\mathrm{C}$ substrate can affect Rs. The $\mathrm{C}$ substrate comes from SOC, and the recalcitrant degree of SOC determines the decomposition rate. In other words, the higher the molecular weight, the more complex the structure and the more stable the chemical bonds, the harder SOC decomposition. Soil microbes prefer the labile C substrate, especially when nutrient availability increases (Edwards et al., 2011). Increasing nutrient availability can also induce microbes to reduce the expression of ligninolytic genes (Edwards et al., 2011) and decrease their enzyme production, which is responsible for recalcitrant C decomposition (Sinsabaugh et al., 2015). Alkyl-carbon, O-alkyl-carbon (O-Alkyl-C), aromatic-carbon (Aromatic-C), and carbonyl-carbon (Carbonyl-C) are major components of SOC; in general, O-Alkyl-C, Aromatic-C, and Carbonyl-C are more recalcitrant as compared with Alkyl-C (Dou et al., 2008).

Although the effects of nitrogen $(\mathrm{N})$ addition and soil temperature on Rs have been widely studied, the relationship between maize stalk retention and seedtime Rs is not yet fully understood. Our objective was to find the relationship between maize stalk retention and seedtime Rs. In the present study, we hypothesized that long-term maize stalk retention not only altered soil temperature and soil moisture, but also altered the $\mathrm{C}$ composition and soil microbial abundance, which could alter Rs.

\section{MATERIALS AND METHODS}

\section{Study site description}

The study site is located in Huashishan County, Siping City, Jilin Province, China ( $\left.43.31^{\circ} \mathrm{N}, 124.62^{\circ} \mathrm{E}\right)$, with an annual mean temperature of $4.8^{\circ} \mathrm{C}$, annual precipitation from $522 \mathrm{~mm}$ to $615 \mathrm{~mm}$, and annual accumulated temperature from 2770 to $2910^{\circ} \mathrm{C}$. Spring is from late March to late June. The study site covers approximately 25 ha and was used as the headquarters for highway construction between 1993 and 1997. Since the completion of the highway, the study site has been naturally fallowed until the spring of 2000. According to the USDA soil taxonomy, the soil belongs to Mollisols. According to Chinese soil taxonomy, the great group is Black soils and the soil order is Semi-luvisols. A basic soil test was conducted in the autumn of 2000 and resulted in $13391 \mathrm{mg} \mathrm{SOC} \mathrm{kg}^{-1}, 1192 \mathrm{mg} \mathrm{N} \mathrm{kg}^{-1}, 2473 \mathrm{mg}$ available $\mathrm{P} \mathrm{kg}^{-1}, 1597$ $\mathrm{mg}$ available $\mathrm{K} \mathrm{kg}^{-1}$ in the $0-30 \mathrm{~cm}$ soil depth, and soil $\mathrm{pH}$ values ranged from 6.5 to 7.1 . The proportion of sand, silt, and clay was $57 \%, 13 \%$, and $30 \%$, respectively.

\section{Field experimental design}

The rainfed maize monoculture was the only crop on this study site; maize was planted with a no-till planter, seedtime was between late April and early May, and it was harvested in early October. Mechanical weeding control was applied during the growing period. To limit the experimental factors, no chemical fertilizers or manure were used.

The study was initiated in the year 2000 and two zones of $200 \mathrm{~m}$ wide and $300 \mathrm{~m}$ long were selected; the width was in the east-west direction and the length in the south-north direction. There was a $50 \times 300 \mathrm{~m}$ area between the two zones, and it was fallowed throughout the study and acted as a buffer zone. One zone (CZ) was covered by maize stalk residue (MSR) after harvesting and the other zone (BZ) was left bare after harvesting (Figure 1). The CZ maize stalk was crushed into small pieces $(<5 \mathrm{~cm})$ by maize combine harvesters and BZ maize stalk was picked. The MSR dry mass becomes constant in late October or early November based on experience; to quantify MSR, five $2.25 \mathrm{~m}^{2}$ square blocks were randomly selected in CZ. Subsequently, total MSR was collected and annually weighed every day from 25 October until the average dry mass of two adjacent days was not significantly different $(\mathrm{p}>0.05)$; the average dry mass was used to calculate the amount of MSR in CZ. According to the measurements obtained from 2000 to 2017, average dry mass was $5639 \mathrm{~kg} \mathrm{ha}^{-1}$. Although there was still some MSR in BZ (Figure 1), this study disregarded it. 
Figure 1. Two experimental zones in the study site. (a) Maize stalk residue after harvesting (5639 $\mathrm{kg} \mathrm{ha}^{-1}$ ) and (b) Bare soil after harvesting.

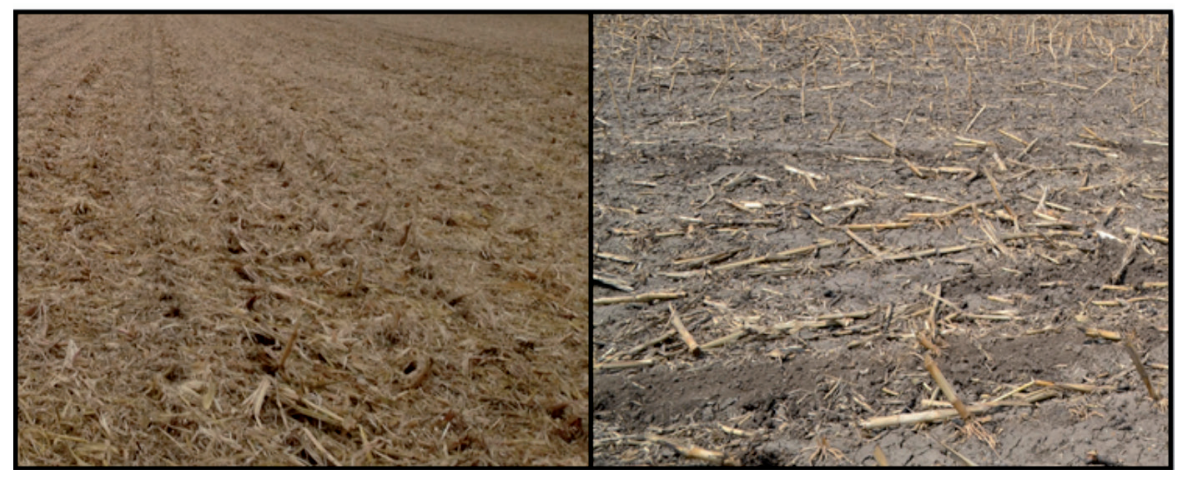

(a)

(b)

Excluding maize stalk management, other management procedures were the same for the two zones. To establish 10 replicates, 10 plots of $10 \times 20 \mathrm{~m}$ were randomly selected in each zone, and 10 random soil sampling points were chosen in each plot for multiple measurements.

\section{Soil sampling}

Field measurements were performed to obtain Rs, soil temperature, and soil moisture, and measurements lasted for $5 \mathrm{~d}$ at each seedtime. Soil cores were collected following the measurement period and transported to the lab for further analyses. Given that seedtime is between late April and early May, sampling dates were selected according to the following rules: (1) to acquire accurate soil moisture values, the starting date needed to be a sunny day and the interval since the last rain more than $2 \mathrm{~d}$ and (2) the measurement period had to be without rain. If it rained, the measured data of the rainy day was discarded, and the rest of the measurements were continued when the weather requirements were met. The sampling schedule is shown in Table 1.

Soil respiration, soil temperature, and soil moisture were measured $24 \mathrm{~h}$ per day. Soil respiration was measured by an automated system (Li-8100A Soil $\mathrm{CO}_{2}$ Flux System, Li-Cor Inc., Lincoln, Nebraska, USA), which was the updated version of Li-8100, a mobile iPhone application that was added to this version. Thus, real-time operational parameters and mean Rs were shown on the iPhone terminal. The Rs rate was measured by the amount of $\mathrm{CO}_{2}$ diffusion per unit area for each time unit. It was approximately $10 \mathrm{~cm}$ away from the survey chamber of the Li-8100 A; a soil temperature and moisture probe (Omega Engineering, Norwalk, Connecticut, USA) was inserted $8 \mathrm{~cm}$ beneath the soil surface, and the Em-50 data logger (Decagon Devices, Pullman, Washington, USA) was connected to the probe with a 1-h monitoring frequency. Finally, mean soil temperature and moisture were collected; soil moisture in the present study referred to soil volumetric water content.

Soil cores used for lab analyses were collected with soil augers. The soil auger was $5 \mathrm{~cm}$ in diameter and $10 \mathrm{~cm}$ in depth. For each replicate, 10 soil cores were mixed so as to constitute one composite sample. These soil samples were immediately brought to the lab and then sieved ( $2 \mathrm{~mm}$ mesh) to remove rocks, visible roots, and debris (Guo et al., 2017). A soil subsample was then air-dried at room temperature $\left(25^{\circ} \mathrm{C}\right)$, ground with a mill, and passed through a $0.25 \mathrm{~mm}$ sieve. This subsample was used to analyze soil $\mathrm{N}$ content, $\mathrm{SOC}$ content as well as $\mathrm{C}$ composition. The other subsample was kept at $4{ }^{\circ} \mathrm{C}$ and was used to analyze soil microbial communities and their microbial abundances.

\section{Soil analyses}

The phospholipid fatty acid (PLFA) technique was used to analyze soil microbial communities and their microbial abundances, the Sherlock Chromatographic Analysis System (MIDI, Newark, Delaware, USA) was applied, and the

Table 1. Soil sampling schedule.

\begin{tabular}{lccr}
\hline & 2015 & 2016 & \multicolumn{1}{c}{2017} \\
\hline Soil respiration & 20-24 April & 23-25 April,30 April-1 May & $21-25$ April \\
Soil temperature & 20-24 April & 23-25 April,30 April-1 May & $21-25$ April \\
Soil moisture & 20-24 April & 23-25 April,30 April-1 May & $21-25$ April \\
Soil cores & 24 April & 1 May & 25 April \\
\hline
\end{tabular}


PLFAs were extracted from the soil sample and kept at $4{ }^{\circ} \mathrm{C}$ according to the the detailed procedure described by Bossio and Scow (1998). The fatty acid nomenclature used in the present study was the same as the one used by Zak et al. (2000).

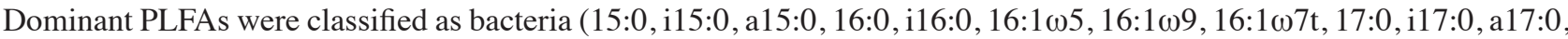

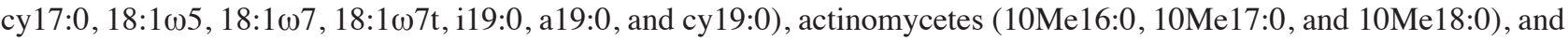

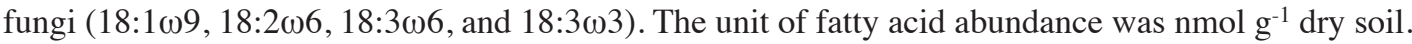

Soil N content and SOC content were tested with a vario MICRO cube (Elementar Co. Ltd., Langenselbold, Germany). The SOC chemical composition was analyzed using the solid-state ${ }^{13} \mathrm{C}$ nuclear magnetic resonance (NMR) spectroscopy by the cross polarization and magic-angle spinning technique. To enhance NMR sensitivity, the soil sample was further managed as described by Schmidt et al. (1997). The Bruker AVANCE II spectrometer (Bruker Corporation, Switzerland) was used to obtain the NMR spectra and the procedure was the same as the one described by Guo et al. (2017). According to Wagai et al. (2013) and Panettieri et al. (2014), specific C molecules reflect specific chemical shift regions. The recalcitrant level from hard to easy was ordered as Carbonyl-C > Aromatic-C > O-Alkyl-C > Alkyl-C; these four C molecules corresponded to four chemical shift regions of 166 to $210 \mathrm{mg} \mathrm{kg}^{-1}, 111$ to $165 \mathrm{mg} \mathrm{kg}^{-1}, 46$ to $110 \mathrm{mg} \mathrm{kg}^{-1}$, and 0 to $45 \mathrm{mg} \mathrm{kg}^{-1}$ (Wagai et al., 2013; Panettieri et al., 2014). The specific $\mathrm{C}$ molecule content was obtained by integrating the corresponding spectral regions.

\section{Data analysis}

The SPSS 22.0 software for Windows (IBM, Armonk, New York, USA) was used in the present study to perform statistical analyses; Student's $t$ test was used to confirm whether the difference between stalk retention and stalk removal was significant, and the comparative items included Rs, soil temperature, soil moisture, soil N content, SOC content, specific $\mathrm{C}$ molecule content, and specific microbial abundance. In addition, redundancy analysis (RDA) was performed to determine to what extent stalk retention, soil temperature, and soil moisture could explain the differences in Rs, soil $\mathrm{N}$ content, SOC content, and soil microbial abundance as well as $\mathrm{C}$ molecule content.

\section{RESULTS}

\section{Soil respiration rates}

The Rs rates are displayed in Figure 2; they were averaged across three seedtimes and the Rs rate for $\mathrm{CZ}$ was $4.11 \mu \mathrm{g} \mathrm{CO}_{2}$ $\mathrm{g}^{-1}$ soil $\mathrm{h}^{-1}$, while the Rs rate for BZ was $4.99 \mu \mathrm{g} \mathrm{CO}_{2} \mathrm{~g}^{-1}$ soil h$^{-1}$. The BZ Rs rates were higher than the $\mathrm{CZ}$ rates for the three seedtimes. The Rs differences between the two treatments were $0.64,0.34$, and $0.76 \mu \mathrm{g} \mathrm{CO}_{2} \mathrm{~g}^{-1}$ soil h$^{-1}$ for 2015 , 2016, and 2017, respectively. Further statistical analyses indicated that the yearly Rs difference was significant (2015: $\mathrm{t}_{9}=$ $\left.22.6, \mathrm{p}<0.05 ; 2016: \mathrm{t}_{9}=12.1, \mathrm{p}<0.05 ; 2017: \mathrm{t}_{9}=5.9, \mathrm{p}<0.05\right)$. In addition, $\mathrm{Rs}$ for $\mathrm{CZ}$ had a decreasing trend from 2015 to 2017 and the decreasing value was $0.45 \mu \mathrm{g} \mathrm{CO}_{2} \mathrm{~g}^{-1}$ soil h$^{-1}$, while Rs for BZ had no such decreasing trend.

Figure 2. Soil respiration (Rs) rates at three seedtimes.

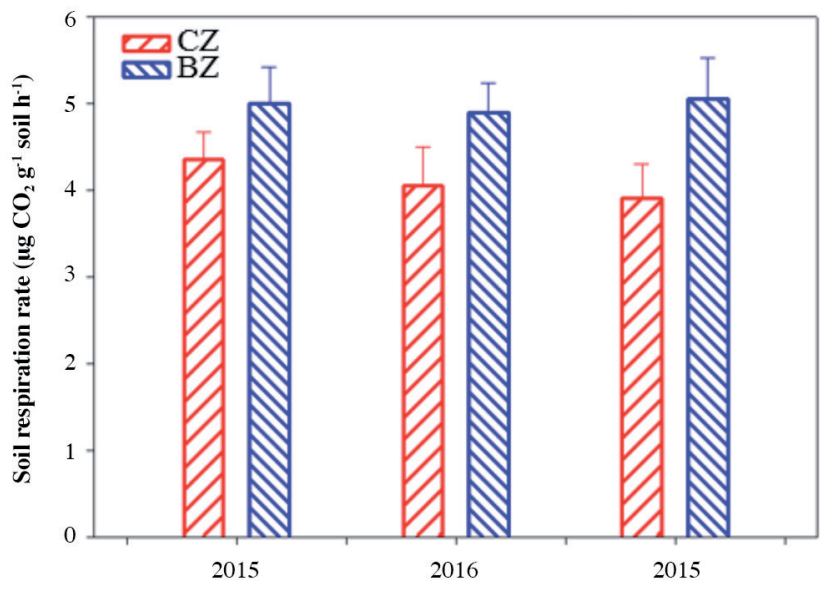

The Rs rates in the zone covered by maize stalk residue after harvesting (CZ) were $4.36,4.06$, and $3.91 \mu \mathrm{g} \mathrm{CO}_{2} \mathrm{~g}^{-1}$ soil $\mathrm{h}^{-1}$ for 2015, 2016, and 2017, respectively. The Rs rates in the zone left bare after harvesting (BZ) were 5.00, 4.90 , and $5.06 \mu \mathrm{g} \mathrm{CO}_{2} \mathrm{~g}^{-1}$ soil h $\mathrm{h}^{-1}$ for 2015,2016 , and 2017, respectively. Error bars indicate standard deviations. 


\section{Soil temperature, soil moisture, soil $\mathbf{N}$ content, and soil organic carbon content}

Since this experiment was initiated, maize stalk retention and maize stalk removal has been implemented for $15 \mathrm{yr}$. Compared with the test results that were obtained in the autumn of 2000, the soil $\mathrm{N}$ content and SOC content in CZ increased, while the soil $\mathrm{N}$ content and SOC content in BZ decreased (Table 2). Table 2 also demonstrates that the soil temperature, soil moisture, soil $\mathrm{N}$ content, and SOC content were different between the two treatments. In general, BZ soil temperatures were higher than in $\mathrm{CZ}$; however, values in $\mathrm{CZ}$ were higher than in $\mathrm{BZ}$ for other soil properties including soil moisture, soil $\mathrm{N}$ content, and SOC content.

As for the three seedtimes in 2015, 2016, and 2017, BZ soil temperatures were $26.6 \%, 20 \%$, and $28.6 \%$ higher than in $\mathrm{CZ}$, soil moisture in $\mathrm{CZ}$ was $14.8 \%, 12.7 \%$, and $22 \%$ higher than in $\mathrm{BZ}$, soil $\mathrm{N}$ content in $\mathrm{CZ}$ was $2.67 \%, 5.76 \%$, and $7.99 \%$ higher than in BZ, and SOC content in $\mathrm{CZ}$ was $6.93 \%, 12.99 \%$, and $22.34 \%$ higher than in BZ.

Statistical analyses indicated that soil temperatures between the two treatments had significant differences (2015: $\left.\mathrm{t}_{9}=16.2, \mathrm{p}<0.05 ; 2016: \mathrm{t}_{9}=15.3, \mathrm{p}<0.05 ; 2017: \mathrm{t}_{9}=9.9, \mathrm{p}<0.05\right)$. The same significant differences were found for soil moisture $\left(2015: \mathrm{t}_{9}=43.1, \mathrm{p}<0.05 ; 2016: \mathrm{t}_{9}=21.4, \mathrm{p}<0.05 ; 2017: \mathrm{t}_{9}=22.7, \mathrm{p}<0.05\right)$, soil $\mathrm{N}$ content (2015: $\left.\mathrm{t}_{9}=3.6, \mathrm{p}<0.05 ; 2016: \mathrm{t}_{9}=4.5, \mathrm{p}<0.05 ; 2017: \mathrm{t}_{9}=6.2, \mathrm{p}<0.05\right)$, and SOC content $\left(2015: \mathrm{t}_{9}=2.9, \mathrm{p}<0.05\right.$; 2016: $\left.\mathrm{t}_{9}=7.1, \mathrm{p}<0.05 ; 2017: \mathrm{t}_{9}=8.6, \mathrm{p}<0.05\right)$.

Regarding CZ, further statistical analyses showed that the difference of soil $\mathrm{N}$ content was significant $\left(\mathrm{t}_{9}=12.1\right.$, $\mathrm{p}<0.05)$ between 2015 and 2016 as well as SOC content $\left(t_{9}=9.1, p<0.05\right)$; however, there was nonsignificant difference for soil $\mathrm{N}$ content $\left(\mathrm{t}_{9}=1.71, \mathrm{p}=0.35\right)$ or SOC content $\left(\mathrm{t}_{9}=1.68, \mathrm{p}=1.43\right)$ between 2016 and 2017. As for BZ, there was a very small decrease in SOC content from 2015 to 2017, but there was nonsignificant difference in soil $\mathrm{N}$ content $\left(2015-2016: \mathrm{t}_{9}=0.32, \mathrm{p}=0.17 ; 2016-2017: \mathrm{t}_{9}=0.91, \mathrm{p}=0.35\right)$ or $\mathrm{SOC}$ content $\left(2015-2016: \mathrm{t}_{9}=1.13\right.$, $\left.\mathrm{p}=1.39 ; 2016-2017: \mathrm{t}_{9}=1.67, \mathrm{p}=0.91\right)$ between the three seedtimes.

\section{Soil microbial communities and their microbial abundances}

Soil microbial communities and their microbial abundances are shown in Figure 3. Seedtimes from 2015 to 2017 exhibited decreasing trends of total PLFA, bacteria, actinomycetes, and fungi in both CZ and BZ. Averaged across the three seedtimes, means for PLFA, bacteria, actinomycetes, and fungi were $296.7,135.0,75.0$, and $24.3 \mathrm{nmol} \mathrm{g}^{-1} \mathrm{dry}$ soil in $\mathrm{CZ}$ and 326.0, 153.0, 91.6, and $31.6 \mathrm{nmol} \mathrm{g}^{-1}$ dry soil in BZ, respectively.

Statistical analyses showed that mean PLFA between CZ and BZ had a significant difference $\left(\mathrm{t}_{29}=3.76, \mathrm{p}<0.01\right)$. The same significant differences were found in the means for bacteria $\left(\mathrm{t}_{29}=4.41, \mathrm{p}<0.01\right)$, actinomycetes $\left(\mathrm{t}_{29}=3.11\right.$, $\mathrm{p}<0.01)$, and fungi $\left(\mathrm{t}_{29}=5.51, \mathrm{p}<0.01\right)$.

Statistical analyses based on two adjacent seedtimes were performed to compare whether CZ or BZ had significant differences in total PLFA, bacteria, actinomycetes, and fungi; the calculated t values are shown in Table 3 and because there were 10 replicates, the degrees of freedom of the t-test was 9 .

Table 3 expresses all the calculated $t$ values based on the experimental data of two adjacent seedtimes. Regarding CZ, there were significant differences in total PLFA, bacteria, actinomycetes, and fungi between two adjacent seedtimes. As for BZ, there were significant differences in total PLFA and bacteria, but there were nonsignificant differences in actinomycetes and fungi between two adjacent seedtimes.

Table 2. Soil temperature, soil moisture, soil N content, and soil organic carbon (SOC) content.

\begin{tabular}{lcccc}
\hline & & 2015 & 2016 & 2017 \\
\hline Soil temperature, ${ }^{\circ} \mathrm{C}$ & $\mathrm{CZ}$ & $15 \pm 0.7$ & $20 \pm 0.5$ & $14 \pm 0.6$ \\
& $\mathrm{BZ}$ & $19 \pm 0.6$ & $24 \pm 0.4$ & $18 \pm 0.4$ \\
Soil moisture, \% & $\mathrm{CZ}$ & $70 \pm 3$ & $75 \pm 7$ & $72 \pm 6$ \\
& $\mathrm{BZ}$ & $61 \pm 9$ & $63 \pm 2$ & $59 \pm 5$ \\
Soil N content, $\mathrm{mg} \mathrm{kg}^{-1}$ & $\mathrm{CZ}$ & $1536 \pm 23$ & $1598 \pm 49$ & $1608 \pm 46$ \\
& $\mathrm{BZ}$ & $1096 \pm 51$ & $1011 \pm 74$ & $1089 \pm 67$ \\
SOC content, $\mathrm{mg} \mathrm{kg}^{-1}$ & $\mathrm{CZ}$ & $15747 \pm 101$ & $16149 \pm 73$ & $16436 \pm 18$ \\
& $\mathrm{BZ}$ & $12727 \pm 64$ & $12293 \pm 109$ & $12446 \pm 59$ \\
\hline
\end{tabular}

CZ: Zone covered by maize stalk residue after harvesting; BZ: zone left bare after harvesting. Data indicate means \pm standard deviations. 
Figure 3. Abundances of soil microbial communities.

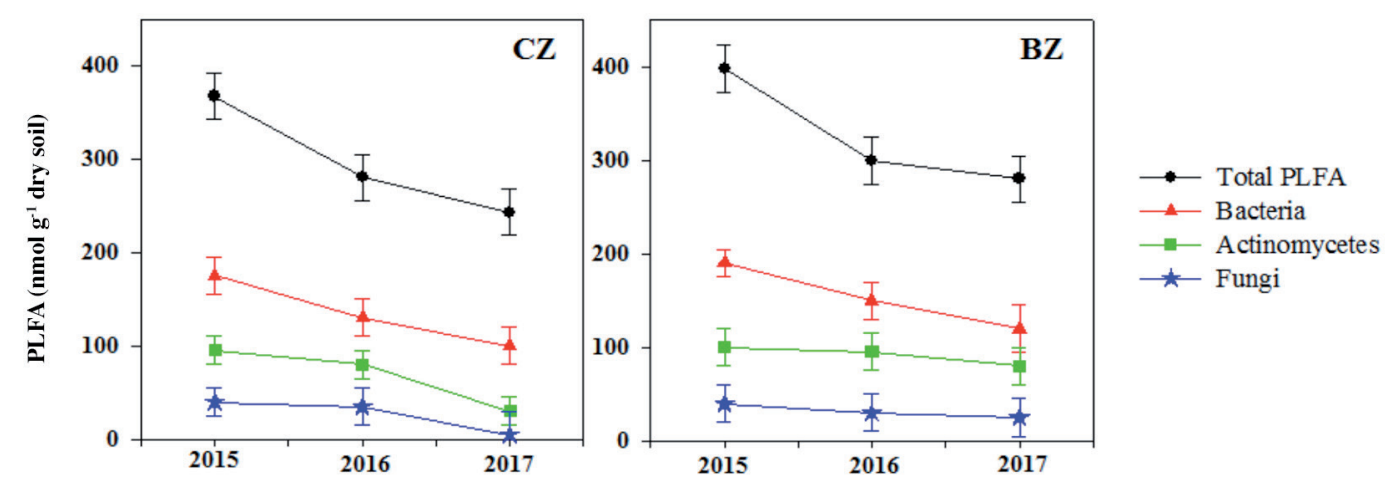

Long-term maize stalk retention resulted in the severe decline of soil actinomycetes and soil fungi. Error bars indicate standard deviations $(\mathrm{n}=10)$.

CZ: Zone covered by maize stalk residue after harvesting; BZ: zone left bare after harvesting; PFLA: phospholipid fatty acids.

Table 3. Calculated $t$ values based on microbial abundance data of two adjacent seedtimes.

\begin{tabular}{llcc}
\hline Comparison year & & $2017-2016$ & $2016-2015$ \\
\hline Total PLFA & $\mathrm{CZ}$ & $3.65^{*}$ & $3.29^{*}$ \\
\multirow{3}{*}{ Bacteria } & $\mathrm{BZ}$ & $4.57^{*}$ & $3.97^{*}$ \\
& $\mathrm{CZ}$ & $3.91^{*}$ & $4.12^{*}$ \\
Actinomycetes & $\mathrm{BZ}$ & $3.84^{*}$ & $3.76^{*}$ \\
& $\mathrm{CZ}$ & $3.39^{*}$ & $4.91^{*}$ \\
Fungi & $\mathrm{BZ}$ & 0.81 & 0.67 \\
& $\mathrm{CZ}$ & $3.29^{*}$ & $5.13^{*}$ \\
\hline
\end{tabular}

*Significant at the 0.1 probability level.

CZ: Zone covered by maize stalk residue after harvesting; BZ: zone left bare after harvesting; PFLA: phospholipid fatty acids.

\section{Carbon composition of soil organic content}

Figure 4 demonstrates that long-term maize stalk retention resulted in a different SOC chemical composition. Averaged across three seedtimes, the mean percentages of Alkyl-C were 25.6 and $35.0 \mathrm{in} \mathrm{CZ}$ and BZ, respectively, and the mean percentages of Carbonyl-C were 13.3 and 13.0 in $\mathrm{CZ}$ and BZ, respectively. The Alkyl-C percentages between CZ and BZ were significantly different $\left(2015: \mathrm{t}_{9}=4.32, \mathrm{p}<0.05 ; 2016: \mathrm{t}_{9}=3.13, \mathrm{p}<0.05 ; 2017: \mathrm{t}_{9}=3.19, \mathrm{p}<0.05\right)$ for the three seedtimes. The O-Alkyl-C percentages between CZ and BZ were significantly different $\left(2015: \mathrm{t}_{9}=2.73, \mathrm{p}<0.05 ; 2017\right.$ : $\left.\mathrm{t}_{9}=2.39, \mathrm{p}<0.05\right)$ for the 2015 and 2017 seedtimes. The O-Alkyl-C percentage between CZ and BZ had nonsignificant difference for the 2016 seedtime (Table 4), the percentages of Aromatic-C and Carbonyl-C between CZ and BZ had nonsignificant difference (Table 4) for the three seedtimes. As for CZ, the Alkyl-C decreased by 4\%, Carbonyl-C increased by $3 \%$ for the 2015 to 2017 seedtimes. Meanwhile, BZ exhibited percentages of Alkyl-C, O-Alkyl-C, Aromatic-C, and Carbonyl-C that had nonsignificant differences (Table 5) between the three seedtimes.

\section{Correlation analyses}

Redundancy analysis was used to explain the correlations among Rs, maize stalk retention, soil temperature, soil moisture, soil $\mathrm{N}$ content, SOC content, soil microbial community, soil microbial abundance, and C composition. Figure 5 illustrates that maize stalk retention together with soil temperature, soil moisture, soil $\mathrm{N}$ content, and SOC content could explain $89 \%$ of the primitive variables (soil respiration, soil microbial abundance, and C composition) used in the present study. In general, Rs and Alkyl-C were explained by the same factors, and Rs was positively correlated with soil 
Figure 4. Soil organic carbon compositions of the two treatments.
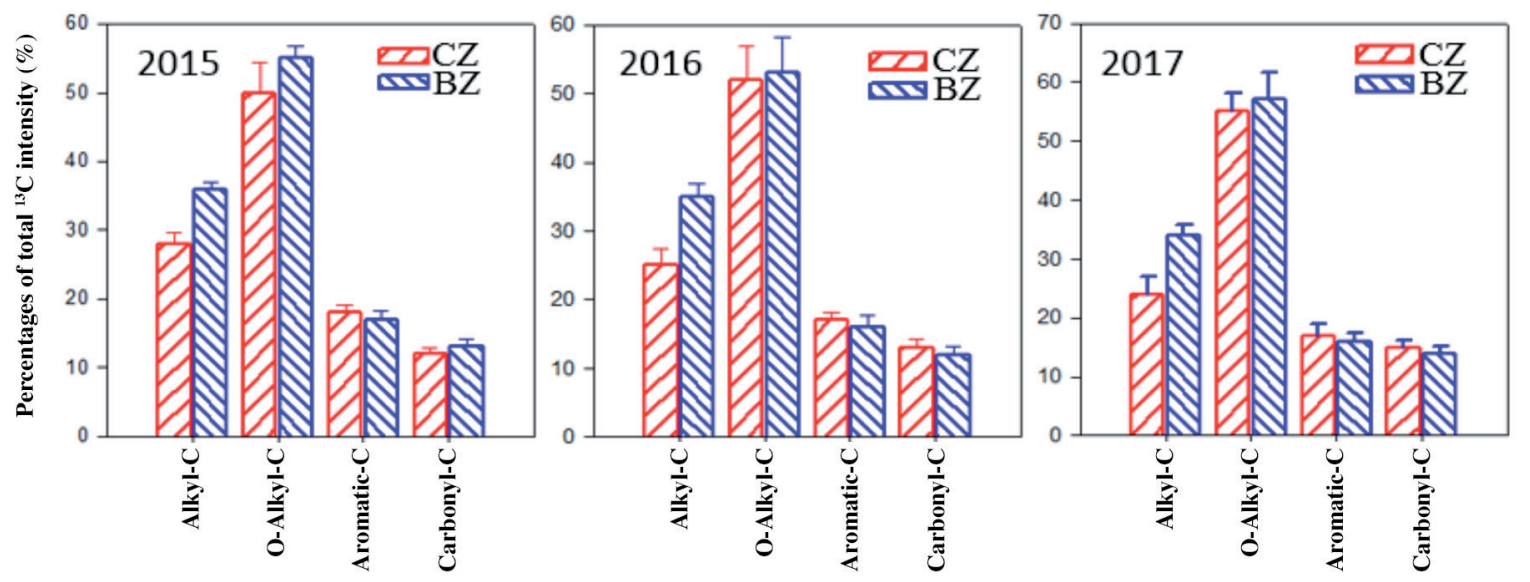

In general, the labile $\mathrm{C}$ substrate (Alkyl-C) in $\mathrm{CZ}$ was less than in $\mathrm{BZ}$; the relative recalcitrant $\mathrm{C}$ substrates (aromatic-C and carbonyl-C) in CZ were slightly higher than in BZ.

Error bars indicate standard deviations $(\mathrm{n}=10)$.

CZ: Zone covered by maize stalk residue after harvesting; BZ: zone left bare after harvesting.

Table 4. Calculated $\mathrm{t}$ values based on specific $\mathrm{C}$ content in $\mathrm{CZ}$ and BZ.

\begin{tabular}{lcll}
\hline Comparison year & 2017 & 2016 & 2015 \\
\hline Alkyl-C & $3.19^{*}$ & $3.31^{*}$ & $4.32^{*}$ \\
O-Alkyl-C & $2.39^{*}$ & 1.21 & $2.73^{*}$ \\
Aromatic-C & 1.82 & 0.97 & 0.99 \\
Carbonyl-C & 1.34 & 1.76 & 1.44 \\
\hline
\end{tabular}

*Significant at the 0.05 probability level $(\mathrm{n}=10)$.

CZ: Zone covered by maize stalk residue after harvesting; BZ: zone left bare after harvesting.

Table 5. Calculated $t$ values based on specific $C$ content of two adjacent seedtimes.

\begin{tabular}{llcc}
\hline Comparison year & & $2017-2016$ & $2016-2015$ \\
\hline Alkyl-C & $\mathrm{CZ}$ & $2.69^{*}$ & $3.32^{*}$ \\
& $\mathrm{BZ}$ & 0.47 & 2.09 \\
O-Alkyl-C & $\mathrm{CZ}$ & 1.29 & 1.14 \\
& $\mathrm{BZ}$ & 1.36 & 1.37 \\
Aromatic-C & $\mathrm{CZ}$ & 1.33 & 0.49 \\
& $\mathrm{BZ}$ & 0.87 & 1.26 \\
Carbonyl-C & $\mathrm{CZ}$ & $1.93^{* *}$ & 0.77 \\
& $\mathrm{BZ}$ & 1.15 & 0.59 \\
\hline
\end{tabular}

*Significant at the 0.05 probability level. **Significant at the 0.1 probability level $(\mathrm{n}=10)$.

temperature $(\mathrm{p}<0.01)$ and negatively correlated with soil moisture $(\mathrm{p}<0.01)$. Alkyl-carbon $(\mathrm{p}<0.05)$ and O-Alkyl-C $(\mathrm{p}<0.05)$ were positively correlated with soil temperature. Total PLFA $(\mathrm{p}<0.05)$, bacteria $(\mathrm{p}<0.05)$, actinomycetes $(\mathrm{p}<0.05)$, and fungi $(\mathrm{p}<0.05)$ were also positively correlated with soil temperature. On the other hand, Aromatic-C $(\mathrm{p}<0.05)$ and Carbonyl-C $(\mathrm{p}<0.05)$ were positively correlated with soil moisture. 
Figure 5. Redundancy analyses of soil respiration (Rs), soil microbial communities, and soil organic carbon (SOC) compositions.

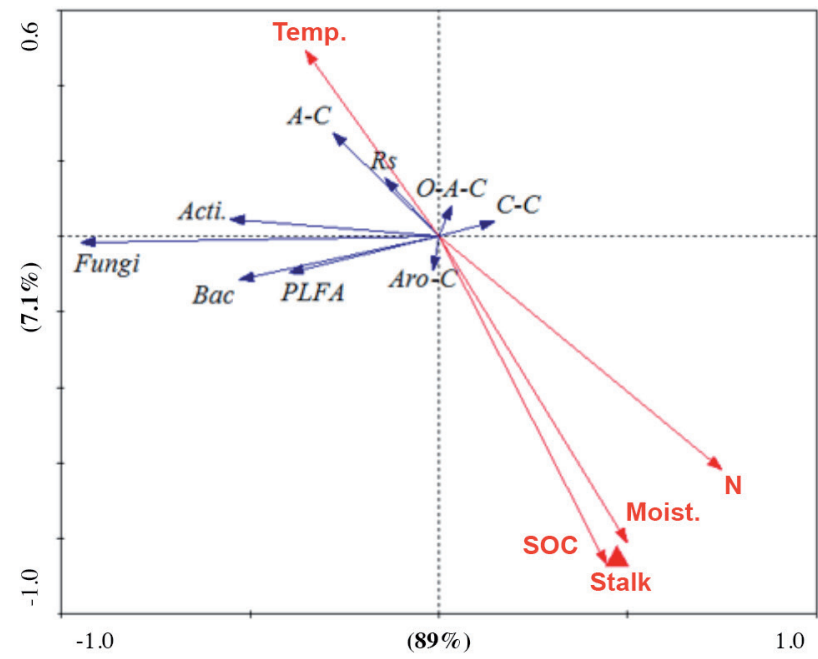

Stalk: Zone covered by maize stalk after harvesting; Moist.: soil moisture; N: soil N content; Temp.: soil temperature; Acti.: actinomycetes; Bac.: bacteria; A-C: alkyl-C; O-A-C: O-alkyl-C; Aro-C: aromatic-C; C-C: carbonyl-C; PFLA: phospholipid fatty acids.

\section{DISCUSSION}

Maize stalk retention and maize stalk removal was adopted in this study site $15 \mathrm{yr}$ ago when this experiment started. Table 2 indicates that during the same measuring period, the soil temperatures in $\mathrm{CZ}$ were lower than those in BZ. Table 2 also illustrates that maize stalk retention had a positive effect on retaining soil moisture, improving soil $\mathrm{N}$ content as well as SOC content, all of which were accordance with previous studies (Gentile et al., 2011; Ismaili et al., 2015; Araya et al., 2016).

Although maize stalk retention greatly benefits soil nutrient replenishment and environmental protection (Nyakudya and Stroosnijder, 2015; Turmel et al., 2015), the study site has a long winter from late October to late March and the average winter temperature was $-17^{\circ} \mathrm{C}$ (Gao et al., 2015). Retained MSR did not completely decay every year and longterm maize stalk retention therefore did not increase soil microorganisms (Wegner et al., 2015) but resulted in a thick residue crust (Jia et al., 2010). The residue crust absorbed substantial solar energy before solar radiation reached the soil surface, thus maize stalk retention decreases soil temperature as compared with maize stalk removal (Treseder, 2008; Lu et al., 2011; Zhou et al., 2014; Sorensen et al., 2016; Guo et al., 2017; Wang et al., 2017). However, stalk retention benefits soil moisture retention (Slawinski et al., 2012; Song et al., 2013). In CZ, soil temperature was lower than in BZ, but soil moisture in CZ was higher than in BZ (Table 2). Since 2000, maize stalk management was the only difference between $\mathrm{CZ}$ and $\mathrm{BZ}$, thus the differences between $\mathrm{CZ}$ and $\mathrm{BZ}$ might be attributed to maize stalk retention. Redundancy analyses implied that Rs was positively correlated with soil temperature, whereas it was negatively correlated with soil moisture (Figure 5); therefore, the differences in soil temperature and soil moisture between CZ and BZ could explain the Rs difference.

There were also differences in soil microbial abundances for the two treatments, mean PLFA, bacteria, actinomycetes, and fungi in $\mathrm{CZ}$ were all lower than in BZ (Figure 3). In addition, the abundance of actinomycetes and fungi was not significantly reduced in BZ but was significantly reduced in CZ (Table 3); the Rs difference could therefore be related to the reduction of soil microbial abundances.

On the other hand, maize stalk retention favored soil $\mathrm{N}$ replenishment (Table 2). Soil $\mathrm{N}$ addition significantly accelerated the decomposition of labile soil $\mathrm{C}$ fractions, while further stabilizing soil $\mathrm{C}$ compounds in heavier, mineralassociated fractions. High $\mathrm{N}$ availability may also depress the 'microbial $\mathrm{N}$ mining' process; therefore, microbes preferred to use labile substrates to acquire N from SOC (Craine et al., 2007; Edwards et al., 2011; Sinsabaugh et al., 2015). The recalcitrant level from hard to easy should be ordered as Carbonyl-C $>$ Aromatic-C $>$ O-Alkyl-C $>$ Alkyl-C (Dou et al., 
2008; Edwards et al., 2011; Sinsabaugh et al., 2015). Although SOC content in CZ was higher than in BZ (Table 2), redundancy analyses showed that Alkyl-C was positively correlated with soil temperature, negatively correlated with soil moisture as well as soil $\mathrm{N}$ content (Figure 5). Figure 4 illustrates that the Alkyl-C percentage in $\mathrm{CZ}$ was lower than in $\mathrm{BZ}$, while the percentages of Aromatic-C and Carbonyl-C were slightly higher than in BZ. The different $\mathrm{C}$ compositions contribute in explaining the Rs difference, especially in the Alkyl-C fraction.

\section{CONCLUSIONS}

Applying maize stalk residue (MSR) to cover the soil surface reduces seedtime soil respiration (Rs) due to soil properties altered by long-term maize stalk retention, such as decreasing soil temperature and increasing soil moisture, soil $\mathrm{N}$ content, and soil organic carbon (SOC) content. In addition, soil microbial abundances as well as the C compositions changed, and these changes also contribute to the Rs difference. Maize stalk retention reduced Rs at seedtime in the present study and is an effective method of soil C sequestration. The present study also has some limitations, for example, the quantitative relationship between stalk residue and Rs is still unclear, but this will be for future research work.

\section{ACKNOWLEDGEMENTS}

This work was supported by the International Scientific and Technological Cooperation Project 20180414074GH, National Key Research and Development Plan (2017YFD0700904), China Postdoctoral Science Foundation Grant (801171030419), and Postdoctoral Research Start-up Funds (801171050419).

\section{REFERENCES}

Araya, T., Nyssen, J., Govaerts, B., Deckers, J., Sommer, R., Bauer, H., et al. 2016. Seven years resource-conserving agriculture effect on soil quality and crop productivity in the Ethiopian drylands. Soil and Tillage Research 163:99-109.

Bossio, D.A., and Scow, K.M. 1998. Impacts of carbon and flooding on soil microbial communities: Phospholipid fatty acid profiles and substrate utilization patterns. Microbial Ecology 35:265.

Chavarría, D.N., Verdenelli, R.A., Muñoz, E.J., Conforto, C., Restovich, S.B., Andriulo, A.E., et al. 2016. Soil microbial functionality in response to the inclusion of cover crop mixtures in agricultural systems. Spanish Journal of Agricultural Research 14:e0304.

Condron, L., Stark, C., O'Callaghan, M., Clinton, P., and Huang, Z. 2010. The role of microbial communities in the formation and decomposition of soil organic matter. p. 81-118. In Dixon, G., and Tilston, E. (eds.) Soil microbiology and sustainable crop production. Springer, Dordrecht, The Netherlands.

Craine, J.M., Morrow, C., and Fierer, N. 2007. Microbial nitrogen limitation increases decomposition. Ecology 88:2105.

Dou, S., Zhang, J.J., and Li, K. 2008. Effect of organic matter applications on 13C-NMR spectra of humic acids of soil. European Journal of Soil Science 59:532-539.

Edwards, I.P., Zak, D.R., Kellner, H., Eisenlord, S.D., and Pregitzer, K.S. 2011. Simulated atmospheric N deposition alters fungal community composition and suppresses ligninolytic gene expression in a northern hardwood forest. PLOS ONE 6:e20421.

Fóti, S., Balogh, J., Nagy, Z., Herbst, M., Pintér, K., Péli, E., et al. 2014. Soil moisture induced changes on fine-scale spatial pattern of soil respiration in a semi-arid sandy grassland. Geoderma 213:245-254.

Gao, F., Wang, T., Li, D., and Wang, Y. 2015. Analysis of climate change in winter in Jilin Province during the last 53 years. Jilin Meteorology 22:31-34.

Gentile, R., Vanlauwe, B., Chivenge, P., and Six, J. 2011. Trade-offs between the short- and long-term effects of residue quality on soil $\mathrm{C}$ and $\mathrm{N}$ dynamics. Plant and Soil 338:159-169.

Guo, H., Ye, C., Zhang, H., Pan, S., Ji, Y., Li, Z., et al. 2017. Long-term nitrogen and phosphorus additions reduce soil microbial respiration but increase its temperature sensitivity in a Tibetan alpine meadow. Soil Biology and Biochemistry 113:26-34.

Isla, R., Guillén, M., and Salmerón, M. 2016. Nitrogen availability effects on gas exchange measurements in field-grown maize (Zea mays L.) under irrigated Mediterranean conditions. Spanish Journal of Agricultural Research 14:e0806.

Ismaili, K., Ismaili, M., and Ibijbijen, J. 2015. The use of ${ }^{13} \mathrm{C}$ and ${ }^{15} \mathrm{~N}$ based isotopic techniques for assessing soil $\mathrm{C}$ and $\mathrm{N}$ changes under conservation agriculture. European Journal of Agronomy 64:1-7.

Jia, H.L., Ma, C.L., Li, H.Z., and Chen, Z.L. 2010. Tillage soil protection of black soil zone in northeast of China based on analysis of conservation tillage in the United States. Transactions of Chinese Society of Agricultural Machinery 41:28-34.

Koiter, A.J., and Lobb, D.A. 2008. Characterization of soil surface properties following disturbance of a clay soil in southern Manitoba. Soil and Tillage Research 100:99-107. 
Lu, M., Zhou, X., Luo, Y., Yang, Y., Fang, C., Chen, J., et al. 2011 . Minor stimulation of soil carbon storage by nitrogen addition: A meta-analysis. Agricultural Ecosystem and Environment 140:234-244.

Nyakudya, I.W., and Stroosnijder, L. 2015. Conservation tillage of rainfed maize in semi-arid Zimbabwe: A review. Soil and Tillage Research 145:184-197.

Panettieri, M., Knicker, H., Murillo, J.M., Madejón, E., and Hatcher, P.G. 2014. Soil organic matter degradation in an agricultural chronosequence under different tillage regimes evaluated by organic matter pools, enzymatic activities and CPMAS ${ }^{13} \mathrm{C}$ NMR. Soil Biology and Biochemistry 78:170-181.

Qin, S., Zhou, W., Li, Z., and Lyu, D. 2016. Effects of rhizobacteria on the respiration and growth of Cerasus sachalinensis Kom. seedlings. Spanish Journal of Agricultural Research 14:e0803.

Ran, Q., Junsheng, L., Zunlan, L., Xiaopu, W., Caiyun, Z., and Bo, T. 2010. Influence of soil microbial and organic acids on soil respiration rate. Journal of Soil and Water Conservation 24:242-245.

Richardson, J., Chatterjee, A., and Darrel, J.G. 2012. Optimum temperatures for soil respiration along a semi-arid elevation gradient in southern California. Soil Biology and Biochemistry 46:89-95.

Schmidt, M.W.I., Knicker, H., Hatcher, P.G., and Kogel-Knabner, I. 1997. Improvement of ${ }^{13} \mathrm{C}$ and ${ }^{15}$ N CPMAS NMR spectra of bulk soils, particle size fractions and organic material by treatment with $10 \%$ hydrofluoric acid. European Journal of Soil Science 48:319-328.

Sinsabaugh, R.L., Belnap, J., Rudgers, J., Kuske, C.R., Martinez, N., and Sandquist, D. 2015. Soil microbial responses to nitrogen addition in arid ecosystems. Frontiers in Microbiology 6:819.

Slawinski, C., Cymerman, J., Witkowska-Walczak, B., and Lamorski, K. 2012. Impact of diverse tillage on soil moisture dynamics. International Agrophysics 26:301-309.

Song, Z.W., Guo, J.R., Zhang, Z.P., Kou, T.J., Deng, A.X., Zheng, C.Y., et al. 2013. Impacts of planting systems on soil moisture, soil temperature and corn yield in rainfed area of Northeast China. European Journal of Agronomy 50:66-74.

Sorensen, P.O., Templer, P.H., and Finzi, A.C. 2016. Contrasting effects of winter snowpack and soil frost on growing season microbial biomass and enzyme activity in two mixed-hardwood forests. Biogeochemistry 128:141-154.

Treseder, K.K. 2008. Nitrogen additions and microbial biomass: a meta-analysis of ecosystem studies. Ecology Letters 11:1111-1120.

Turmel, M.S., Speratti, A., Baudron, F., Verhulst, N., and Govaerts, B. 2015. Crop residue management and soil health: A systems analysis. Agricultural Systems 134:6-16.

Wagai, R., Kishimotomo, A.W., Yonemura, S., Shirato, Y., Hiradate, S., and Yagasaki, Y. 2013. Linking temperature sensitivity of soil organic matter decomposition to its molecular structure, accessibility, and microbial physiology. Global Change Biology 19:1114-1125.

Wang, G., Jia, H.L., Tang, L., Lu, Y.L., Guo, L., and Zhuang, J. 2017. Standing corn residue effects on soil frost depth, snow depth and soil heat flux in Northeast China. Soil and Tillage Research 165:88-94.

Wegner, B.R., Kumar, S., Osborne, S.L., Schumacher, T.E., Vahyala, I.E., and Eynard, A. 2015. Soil response to corn residue removal and cover crops in Eastern South Dakota. Soil Science Society of America Journal 79:1179-1187.

Wu, J., Chen, S.T., Hu, Z.H., and Zhang, X. 2015. Soil microbial respiration under different soil temperature conditions and its relationship to soil dissolved organic carbon and invertase. Environmental Science 36:1497-1506.

Zak, D.R., Pregitzer, K.S., Curtis, P.S., and Holmes, W.E. 2000. Atmospheric $\mathrm{CO}_{2}$ and the composition and function of soil microbial communities. Ecological Applications 10:47-59.

Zhou, L., Zhou, X., Zhang, B., Lu, M., Luo, Y., Liu, L., et al. 2014. Different responses of soil respiration and its components to nitrogen addition among biomes: A meta-analysis. Global Change Biology 20:2332. 